\title{
Tin and Antimony As Soil Pollutants Along The Railway Lines
}

\section{Zvjezdana Stančić ( $\nabla$ zvstan@gfv.hr)}

University of Zagreb Faculty of Geotechnical Engineering: Sveuciliste u Zagrebu Geotehnicki Fakultet https://orcid.org/0000-0002-6124-811X

Željka Fiket

Institut Ruđer Bošković: Institut Ruder Boskovic

Andreja Vuger

University of Zagreb Faculty of Geotechnical Engineering: Sveuciliste u Zagrebu Geotehnicki Fakultet

\section{Research Article}

Keywords: Antimony, Tin, Railway, Soil, Pollution, Croatia

Posted Date: September 3rd, 2021

DOI: https://doi.org/10.21203/rs.3.rs-796315/v1

License: (c) (i) This work is licensed under a Creative Commons Attribution 4.0 International License. Read Full License 


\section{Abstract}

Antimony (Sb) and tin ( $\mathrm{Sn}$ ) in soils along railway lines pose a serious environmental risk. The study, conducted at 60 sites along the $160 \mathrm{~km}$ railway line connecting the Croatian capital Zagreb with surrounding smaller settlements and towns, showed pronounced soil Sb and Sn enrichment up to 87 and 33 times the median for European soils, respectively. The total mass fractions of Sb ranged from 0.98 to $52.0 \mathrm{mg} / \mathrm{kg}$ and of Sn from $3.04 \mathrm{mg} / \mathrm{kg}$ to $97.6 \mathrm{mg} / \mathrm{kg}$. The origin of the enrichment is railway traffic, but precise sources are difficult to define, however available literature points to abrasion from brakes, rails, wheels and overhead wires, exhaust fumes from locomotive engines and cargo waste as predominant sources. The comprehensive data analysis suggested that the $\mathrm{Sb}$ and $\mathrm{Sn}$ distribution in soils near railway lines was not only conditioned by natural factors such as soil texture, humus content and soil pH, but also by the distance to the tracks, which is not necessarily linear, the site functionality, the topography and the age of the railway line. Observed soil contamination with antimony and tin requires further research to increase knowledge of the impact of railways on Sb and Sn soil content, and to establish safety distances that will ensure the least possible impact of rail traffic on nearby crops and prevent their excessive entry into the food chain.

\section{Introduction}

The development of transportation, industry, power generation, and agriculture are crucial factors in the economic progress of any country; however, any progress is unfortunately associated with increasing pollution and often leads to contamination of various environmental compartments. Among the most commonly studied inorganic pollutants are various heavy metals and metalloids (hereafter referred to as HMs). While some HMs such as arsenic (As), cadmium (Cd), chromium ( $\mathrm{Cr})$, cobalt $(\mathrm{Co})$, copper $(\mathrm{Cu})$, mercury $(\mathrm{Hg})$, manganese $(\mathrm{Mn})$, nickel $(\mathrm{N})$, lead $(\mathrm{Pb})$ and zinc $(\mathrm{Zn})$ are frequently the subject of research, antimony $(\mathrm{Sb})$ and tin $(\mathrm{Sn})$ are rarely analyzed, although they are frequently used in everyday products.

For example, antimony is mostly used as a flame retardant $\left(\mathrm{Sb}_{2} \mathrm{O}_{3}\right)$ (inhibits fire) in textiles, papers, plastics and adhesives, in brake pads; in alloys (as a hardener of $\mathrm{Pb}$ in $\mathrm{Pb}$ acid batteries, cable sheathing, bullets, component in semiconductors, bearings); stabilizers and catalysts in plastic manufacturing (PET); rubber compounds; additives in tire vulcanization; pigments in paints and varnishes; in ceramics manufacturing (opacifier in enamels); in glass manufacturing; losses; abrasives; antiparasitics, chemicals (Adriano 2001; Clemente 2013), etc.

Tin, on the other hand, has been widely used in protective coatings (tinning) on steel to prevent corrosion, especially in food and beverage cans, which is why canned food is considered the main source of $\mathrm{Sn}$ in human food; in electrical solders (for connecting pipes, electrical and electronic equipment); in the production of alloys (e.g. bronze is about $90 \% \mathrm{Cu}$ and $10 \% \mathrm{Sn}$, pewter contains about $85 \% \mathrm{Sn}$, etc.), some of which are used in the manufacture of brakes, landing gear, engine parts in the automotive and aerospace industries; in additives in foodstuffs and toothpaste $\left(\mathrm{SnCl}_{2}\right)$; in the preparation of organotin compounds with the general formula $\mathrm{R}_{n} \mathrm{SnX}_{3-n}$ ( $\mathrm{R}$ is an alkyl or aryl group, $\mathrm{Sn}$ is in the +4 oxidation state, and $\mathrm{R}$ is an anion or an anionic organic group), which have a wide range of uses, including heat stabilizers in PVC (66\%), catalysts, and various biocides (especially fungicides for agricultural crops, for wood preservation, insecticides, an antifouling paint for boat hulls, as a slime control agent in cooling towers, and others); in glass treatment; in various chemicals, and others (Adriano 2001; Alloway 2013).

Consequently, both elements are released into the environment through various pathways, including mining, smelting, manufacturing and use of their products, and disposal of wastes and sludges. As a result, $\mathrm{Sn}$ and Sb accumulate in the pedosphere, hydrosphere and biosphere and are mostly retained in the environment due to their persistence. Depending on their chemical form and concentration, both trace elements have harmful effects on various living organisms and on human health (Cima 2018; Cooper and Harrison 2009). In the case of Sn, the most hazardous organic compounds (e.g. organotins) are a much more common source of $\mathrm{Sn}$ in soil than inorganic forms and can enter soil through atmospheric deposition, fungicide application, and sewage sludge disposal (Alloway 2013). For Sb, Clemente (2013) found that this metalloid has similar chemical and toxicological properties to As and its toxicity depends on its oxidation state, solubility and interactions with ligands. It is known that $\mathrm{Sb}$ (III) is slightly more toxic than $\mathrm{Sb}(\mathrm{V})$, and human exposure to $\mathrm{Sb}$ (III) can lead to lung, heart, liver, and kidney diseases; however, a true environmental risk assessment emanating from Sb is needed to identify all possible negative effects of this element on different environmental compartments (Clemente 2013).

One of the under-researched sources of HMs pollution is rail transport. Although there are numerous studies worldwide that have investigated the presence of HMs in soil along railway lines, including Canada (Murray et al. 2000; Pollock and St. Clair 2020), China (Chen et. al. 2014a, b; Chen et al. 2018; Liu et al. 2009; Ma et al. 2009; Meng et al. 2018; Zhang et al. 2012, 2013), Czech Republic (Šeda et al. 2017), Germany (Kowarik 1986), India (Alok Gude 2017), Ghana (Akoto et al. 2008), Lithuania (Baltrenas et al. 2009; Vaiškūnaitè and Jasiūnienė 2020), Poland (Dzierżanowski and Gawroński 2012; Malawska and Wiłkomirski 1997, 2000, 2001; Mazur et al. 2013; Mętrak et al. 2015; Radziemska et al. 2016, 2020; Staszewski et al. 2015; Wierzbicka et al. 2015; Wiłkomirski et al. 2011, 2013), Russia (Barcan et al. 1998; Kazantsev 2015), Serbia (Stojic et al. 2017), and Ukraine (Bobryk 2015; Bobryk et al. 2016; Samarska and Zelenko 2018a, b), most of them included less than 10 elements, usually $\mathrm{Cd}, \mathrm{Co}, \mathrm{Cr}, \mathrm{Cu}, \mathrm{Mn}, \mathrm{Ni}, \mathrm{Pb}$ and $\mathrm{Zn}$. In the currently available literature on the environmental impact of rail transport, few studies have included Sb and/or Sn, with Dzierżanowski and Gawroński (2012) investigating the distribution of these two elements in plants, while Wiłkomirski et al. (2013) and Staszewski et al. (2015) included only Sn in their studies of soil and soil and plants, respectively.

In order to increase the knowledge about antimony and tin, rare trace elements emitted by railway traffic, the main objectives of this work are: (a) to determine $\mathrm{Sb}$ and $\mathrm{Sn}$ contents in soils along railway lines in northwestern Croatia, (b) to identify their contamination patterns, and (c) to determine their possible sources.

\section{Materials And Methods}

\section{Study area}


The study covers the northwestern part of Croatia (Fig. 1a), the most densely populated part of the country with a developed railway network. The sampling was conducted along three railway lines: Zagreb Main Station - Varaždin (104 km), Varaždin - Golubovec (34 km) and Varaždin - Ludbreg (23 km) (Fig. 1b). The railway lines are above ground along their entire length.

The studied railway lines are located mainly in the lowlands and partly in the hilly area of the Croatian inland, in the altitude range from 120 to $300 \mathrm{~m}$ a.s.l. The area is covered with abandoned meadows in succession, utilized meadows, cultivated fields, settlements and, to a lesser extent, forests. The climate is temperate continental, belonging to the Cfwbx type according to the Köppen classification and to the humid climate according to the Thornthwaite classification, with mean annual air temperatures of 9 to $11^{\circ} \mathrm{C}$ and mean annual precipitation of 800 to $1100 \mathrm{~mm}$ (Zaninović et al. 2008).

On the above railway lines, the number of trains in 2014 ranged from 5965 to 45969 , depending on the section. The trains carry passengers and goods and are powered by diesel locomotives, diesel engines and, to a lesser extent, electricity. Most of the studied lines are non-electrified single-track lines, except for the section from Zagreb Main Station to Zaprešić with electrified double-track (Fig. 1b). Tracks between stops and stations are located on embankments elevated 0.5 to $2 \mathrm{~m}$ above the surrounding terrain, usually with drainage channels next to them. Tracks and wooden sleepers are laid on a ballast consisting of carbonate rubble (limestone $\left(\mathrm{CaCO}_{3}\right)$ and dolomite $\left(\mathrm{CaCO}_{3} \times \mathrm{MgCO}_{3}\right)$ in varying proportions). Background sample was collected in a beech (Fagus sylvatica

L.) forest, the least modified habitat type, near the Klimen village near Konjščina about 2.5-3 km air distance from the railway line Zagreb Main Station Varaždin.

\section{Sampling and data collection}

Soils were collected from June to July 2014 from a total of 60 sites. The sample from each site is a mixture of three surface soil samples $(0-15 \mathrm{~cm})$ collected $1 \mathrm{~m}$ apart.

All soil samples were air-dried at $20^{\circ} \mathrm{C}$, sieved through a 2-mm sieve to remove the gravel fraction, homogenised using an agate mill (HRN ISO 11464:2009), and stored in plastic bags until further analysis.

To better characterise the samples, all sites were characterised based on four features: i) distance from the tracks, ii) their topography, iii) their function in relation to the railway infrastructure, and iv) age of the railway lines.

According to the topography, the sampling sites can be described as above rail level, at rail level or below rail level, while the sites can be divided into four categories in terms of their function: (a) along railway lines between stations, where trains only pass; (b) stops - the simplest stations with platforms, where trains stop and serve to load and unload passengers; (c) stations - stations with more than one line, platform/s, station building/s and serve to load and unload passengers and freight; and (d) junction stations - the larger stations where at least three or more lines meet, with many tracks, platforms, buildings and other facilities, and serve for loading and unloading of passengers and freight.

\section{Soil properties analysis}

Soil texture was evaluated according to HRN ISO 11277:2011, texture classes according to FAO (2006), soil pH response according to HRN ISO 10390:2005, humus content according to Tjurin method (JDPZ 1966) and classification of soils according to humus content (Gračanin and llijanić 1977).

\section{Sample preparation for ICP-MS}

To analyze the total content of Sb and $\mathrm{Sn}$ in the soil, subsamples $(0.05 \mathrm{~g})$ of the soils were subjected to total digestion in a microwave oven (Multiwave 3000 , Anton Paar, Graz, Austria) in a two-step procedure consisting of digestion with a mixture of $4 \mathrm{~mL}$ nitric acid $\left(\mathrm{HNO}_{3}, 65 \%\right.$, pro analysi, $\mathrm{Kemika}$, Zagreb, Croatia)

- $1 \mathrm{~mL}$ hydrochloric acid ( $\mathrm{HCl}, 36.5 \%$, pro analysis, Kemika, Zagreb, Croatia) - $1 \mathrm{~mL}$ hydrofluoric acid (HF, 48 \%, pro analysi, Kemika, Zagreb, Croatia) followed by the addition of $6 \mathrm{~mL}$ of boric acid $\left(\mathrm{H}_{3} \mathrm{BO}_{3}\right.$, Fluka, Steinheim, Switzerland) (Fiket et al. 2016). After digestion soil samples were further diluted 10-fold, acidified with $2 \%(\mathrm{v} / \mathrm{v}) \mathrm{HNO}_{3}$ (65\%, supra pur, Fluka, Steinheim, Switzerland) and indium (In, $1 \mu \mathrm{gL}^{-1}$ ) was added as internal standard.

\section{Multielement analysis}

The multielement analysis was performed by High Resolution Inductively Coupled Plasma Mass Spectrometry (HR-ICP-MS) using an Element 2 instrument (Thermo, Bremen, Germany). Typical instrument conditions and measurement parameters used throughout the work were reported earlier (Fiket et al. 2016). Standards for multielement analysis were prepared by appropriate dilution of standard solutions for Sn (1.000 +/- $0.002 \mathrm{~g} / \mathrm{L}$, Analytika, Prague, Czech Republic) and Sb (1.000 +/- $0.002 \mathrm{~g} / \mathrm{L}$, Analytika, Prague, Czech Republic). All samples were analyzed for the total concentration of Sb and Sn.

The quality control of analytical procedure was performed by a simultaneous analysis of the blank and the certified reference material for soil (NCS DC 77302, also known as GBW 07410, China National Analysis Center for Iron and Steel, Beijing, China). A good agreement between the analyzed and the certified concentrations within their analytical uncertainties $( \pm 10 \%)$ for all measured elements was obtained (Fiket et al. 2016).

\section{Statistical analysis}

Data were statistically treated using STATISTICA 7.0 (StatSoft, Inc.). Multivariate principal component analysis (PCA) was performed on the data matrix consisting of $\mathrm{Sb}$ and $\mathrm{Sn}$ mass fractions, grain size fractions, texture, humus content, and $\mathrm{pH}\left(\mathrm{pH}_{\mathrm{H} 2 \mathrm{O}}\right.$ and $\left.\mathrm{pH}_{\mathrm{KCl}}\right)$. Differences between groups (distance from railroad tracks, topography, function, and age) were tested by analysis of variance (ANOVA) on ranks followed by pairwise comparison using Dunn's method (STATISTICA 8.0, Stat Soft Inc., USA), with significance level set at $p<0.05$.

\section{Results}


The total mass fractions of $\mathrm{Sn}$ in soil along railway lines in northwestern Croatia ranged from $3.04 \mathrm{mg} / \mathrm{kg}$ to $97.6 \mathrm{mg} / \mathrm{kg}$ (Table 1). The highest Sn content $(97.6 \mathrm{mg} / \mathrm{kg})$ was found at Zaprešić station, Žeinci station $(61.4 \mathrm{mg} / \mathrm{kg})$ and Varaždin station $(52.6 \mathrm{mg} / \mathrm{kg})$. The lowest tin content was detected in the soil at Kupljenovo station $(3.04 \mathrm{mg} / \mathrm{kg})$.

For $\mathrm{Sb}$, the total mass fractions in soil ranged from 0.98 to $52.0 \mathrm{mg} / \mathrm{kg}$. The highest Sb content was found in the soil at Konjščina station ( $52.0 \mathrm{mg} / \mathrm{kg}$ ), Žeinci station $(43.2 \mathrm{mg} / \mathrm{kg})$ and Varaždin station $(27.4 \mathrm{mg} / \mathrm{kg})$. The lowest antimony content was found in the soil at Kaniža station $(0.98 \mathrm{mg} / \mathrm{kg})$.

In the studied soils, the humus content ranges from 1.0-17.7\% with an average of $7.3 \%$ (Table 1). Most of the samples, namely 30 , belong to high humus content soils ( $5-10 \%), 12$ samples belong to medium humus content soils (3-5\%), 11 samples belong to very high humus content soils ( $>10 \%)$ and 7 samples belong to low humus content soils $(1-3 \%)$.

The $\mathrm{pH}_{\mathrm{H} 2 \mathrm{O}}$ of the soil ranges from 6.7 to 8.05 . Out of the 60 samples, 37 samples were slightly alkaline (7.6-8.1) and 23 samples were neutral (6.5-7.5). On the other hand, the $\mathrm{pH}_{\mathrm{KCl}}$ value ranges from 5.48 to 7.9 .

The studied soils were classified into the following textural classes: sandy loam (19 samples), silty loam (18 samples), loam (11 samples), loamy sand (6 samples), sand (3 samples), silt (2 samples) and silty clay loam (1 samples). 
Table 1

Total mass concentrations of Sn and Sb in soils from the northwestern Croatia, humus content, soil reaction and soil texture. Abbreviations: I - loam, IP - loamy

\begin{tabular}{|c|c|c|c|c|c|c|c|c|c|c|c|c|}
\hline $\begin{array}{l}\text { No. } \\
\text { of } \\
\text { site }\end{array}$ & Locality & $\begin{array}{l}\mathrm{Sn} \\
\mathrm{mg} / \mathrm{kg}\end{array}$ & $\begin{array}{l}\mathrm{Sb} \\
\mathrm{mg} / \mathrm{kg}\end{array}$ & $\begin{array}{l}\text { Humus } \\
\text { (\%) }\end{array}$ & $\underset{(\mathrm{H} 20)}{\mathrm{pH}}$ & $\underset{(\mathrm{KCl})}{\mathrm{pH}}$ & $\begin{array}{l}\text { Coarse } \\
\text { sand } \\
2.0-0.2 \\
\mathrm{~mm}\end{array}$ & $\begin{array}{l}\text { Fine } \\
\text { sand } \\
\\
0.2- \\
0.063 \\
\mathrm{~mm}\end{array}$ & $\begin{array}{l}\text { Coarse } \\
\text { silt } \\
\\
0.063- \\
0.02 \mathrm{~mm}\end{array}$ & $\begin{array}{l}\text { Fine silt } \\
0.02- \\
0.002 \\
\mathrm{~mm}\end{array}$ & $\begin{array}{l}\text { Clay } \\
<0.002 \\
\mathrm{~mm}\end{array}$ & $\begin{array}{l}\text { Texture } \\
\text { class }\end{array}$ \\
\hline 1 & Golubovec & 3.98 & 1.21 & 2.7 & 6.8 & 6.2 & 9.7 & 15.0 & 21.3 & 35.0 & 19.0 & Prl \\
\hline 2 & Lepoglava & 14.5 & 8.71 & 8.7 & 7.1 & 6.7 & 46.9 & 14.7 & 19.1 & 16.5 & 2.8 & $\mathrm{PI}$ \\
\hline 3 & Kaniža & 7.90 & 0.98 & 4.5 & 7.1 & 6.6 & 6.5 & 12.3 & 38.6 & 35.9 & 6.7 & Prl \\
\hline 4 & Ivanec & 8.25 & 1.50 & 6.2 & 7.3 & 6.7 & 23.9 & 19.2 & 26.3 & 25.2 & 5.4 & $\mathrm{Prl}$ \\
\hline 5 & Ivanec & 7.88 & 5.07 & 8.8 & 7.3 & 6.9 & 41.4 & 13.4 & 12.4 & 28.4 & 4.4 & $\mathrm{PI}$ \\
\hline 6 & Novo Cerje & 14.3 & 6.02 & 9.2 & 7.3 & 6.7 & 27.9 & 11.8 & 27.0 & 26.7 & 6.6 & $\mathrm{Prl}$ \\
\hline 7 & Novo Cerje & 9.31 & 1.59 & 3.9 & 7.2 & 6.2 & 1.8 & 2.5 & 44.3 & 41.6 & 9.8 & $\operatorname{Pr}$ \\
\hline 8 & Gojanec & 7.10 & 1.11 & 8.2 & 7.3 & 6.8 & 29.7 & 17.2 & 27.0 & 21.8 & 4.3 & $\mathrm{PI}$ \\
\hline 9 & Donji Kućan & 7.04 & 1.18 & 4.0 & 7.3 & 6.8 & 36.3 & 20.8 & 20.5 & 19.6 & 2.8 & $\mathrm{Pl}$ \\
\hline 10 & Jalžabet & 7.25 & 1.65 & 5.4 & 7.4 & 6.7 & 5.3 & 9.5 & 47.7 & 30.7 & 6.8 & Prl \\
\hline 11 & Martijanec & 7.06 & 1.72 & 4.8 & 6.9 & 6.0 & 11.0 & 22.0 & 37.2 & 23.9 & 5.9 & Prl \\
\hline 12 & Ludbreg & 18.8 & 8.92 & 10.9 & 7.1 & 6.8 & 41.0 & 17.6 & 20.4 & 16.2 & 4.8 & $\mathrm{PI}$ \\
\hline 13 & Ludbreg & 16.2 & 8.62 & 5.2 & 7.6 & 7.3 & 57.3 & 22.0 & 14.6 & 5.6 & 0.5 & IP \\
\hline 14 & Varaždin & 52.6 & 27.4 & 8.5 & 7.7 & 7.1 & 25.9 & 25.6 & 25.0 & 19.3 & 4.2 & $\mathrm{Pl}$ \\
\hline 15 & Varaždin & 14.2 & 9.09 & 2.7 & 8.1 & 7.9 & 48.8 & 15.8 & 18.2 & 15.7 & 1.5 & $\mathrm{PI}$ \\
\hline 16 & Varaždin & 30.7 & 21.4 & 17.7 & 7.8 & 7.1 & 38.3 & 17.9 & 18.8 & 17.8 & 7.2 & $\mathrm{PI}$ \\
\hline 17 & Varaždin - Turčin & 6.63 & 1.06 & 1.2 & 7.7 & 6.8 & 20.3 & 24.7 & 30.3 & 17.1 & 7.6 & I \\
\hline 18 & Tomaševec - Križanec & 8.26 & 1.54 & 3.1 & 7.6 & 6.7 & 5.1 & 10.1 & 55.3 & 24.5 & 5.0 & Prl \\
\hline 19 & Krušljevec & 7.80 & 2.06 & 4.1 & 7.7 & 7.1 & 69.9 & 15.0 & 8.1 & 5.7 & 1.3 & IP \\
\hline 20 & Presečno - Novi Marof & 7.89 & 1.25 & 2.5 & 7.9 & 7.3 & 35.9 & 13.5 & 21.3 & 21.7 & 7.6 & I \\
\hline 21 & Novi Marof & 8.11 & 2.94 & 14.7 & 7.7 & 6.8 & 38.6 & 15.5 & 17.4 & 20.9 & 7.6 & $\mathrm{PI}$ \\
\hline 22 & Mađarevo - Topličica & 6.98 & 1.35 & 2.6 & 7.9 & 7.4 & 53.7 & 24.5 & 8.8 & 11.1 & 1.9 & IP \\
\hline 23 & Podrute & 20.5 & 17.9 & 8.0 & 7.8 & 7.4 & 18.5 & 14.9 & 24.7 & 35.6 & 6.3 & Prl \\
\hline 24 & Podrute & 9.08 & 3.84 & 5.4 & 7.8 & 7.1 & 20.6 & 9.9 & 20.1 & 40.2 & 9.2 & $\mathrm{Prl}$ \\
\hline 25 & Podrute - Budinšćina & 6.54 & 1.36 & 5.5 & 7.7 & 7.2 & 41.5 & 15.1 & 19.4 & 19.5 & 4.5 & $\mathrm{PI}$ \\
\hline 26 & Budinšćina & 14.9 & 8.90 & 12.9 & 7.7 & 7.1 & 42.0 & 15.4 & 14.7 & 20.0 & 7.9 & $\mathrm{PI}$ \\
\hline 27 & Hrašćina Trgovišće & 7.81 & 2.13 & 15.5 & 7.5 & 6.9 & 2.0 & 2.2 & 18.3 & 49.0 & 28.5 & PrGI \\
\hline 28 & Konjšćina & 8.96 & 52.0 & 9.5 & 7.6 & 7.3 & 42.8 & 12.0 & 12.9 & 24.7 & 7.6 & $\mathrm{PI}$ \\
\hline 29 & Donji Lipovec & 9.17 & 1.25 & 1.9 & 7.4 & 5.8 & 0.7 & 5.0 & 39.7 & 43.4 & 11.2 & $\operatorname{Pr}$ \\
\hline 30 & Zlatar Bistrica & 7.25 & 2.00 & 7.0 & 7.3 & 6.7 & 30.9 & 7.0 & 26.7 & 29.6 & 5.8 & Prl \\
\hline 31 & Zlatar Bistrica & 12.0 & 4.33 & 5.1 & 6.7 & 6.8 & 14.7 & 9.7 & 31.3 & 34.6 & 9.7 & Prl \\
\hline 32 & Lovrećan - Poznanovec & 9.07 & 2.28 & 7.1 & 6.8 & 6.8 & 30.0 & 17.0 & 19.0 & 27.0 & 7.0 & I \\
\hline 33 & Zagreb, Main Station & 8.20 & 4.61 & 4.9 & 7.1 & 7.1 & 19.6 & 12.3 & 26.8 & 28.8 & 12.5 & Prl \\
\hline 34 & Zagreb, Main Station & 27.4 & 11.0 & 9.2 & 7.1 & 7.0 & 20.5 & 12.6 & 21.3 & 35.3 & 10.3 & Prl \\
\hline 35 & Zagreb, Main Station & 6.90 & 5.49 & 4.1 & 7.4 & 7.5 & 69.3 & 16.9 & 5.7 & 7.1 & 1.0 & $P$ \\
\hline 36 & Zagreb, Western Station & 10.7 & 5.83 & 5.1 & 7.5 & 7.3 & 59.5 & 13.8 & 11.5 & 12.1 & 3.1 & IP \\
\hline 37 & Zagreb, Western Station & 3.25 & 3.10 & 1.0 & 7.7 & 7.6 & 81.0 & 10.9 & 3.7 & 3.9 & 0.5 & $P$ \\
\hline 38 & $\begin{array}{l}\text { Kustošija - Zagreb, } \\
\text { Main Station }\end{array}$ & 5.58 & 4.06 & 8.6 & 7.5 & 7.2 & 77.5 & 9.1 & 5.6 & 7.2 & 0.6 & $P$ \\
\hline
\end{tabular}




\begin{tabular}{|c|c|c|c|c|c|c|c|c|c|c|c|c|}
\hline $\begin{array}{l}\text { No. } \\
\text { of } \\
\text { site }\end{array}$ & Locality & $\begin{array}{l}\mathrm{Sn} \\
\mathrm{mg} / \mathrm{kg}\end{array}$ & $\begin{array}{l}\mathrm{Sb} \\
\mathrm{mg} / \mathrm{kg}\end{array}$ & $\begin{array}{l}\text { Humus } \\
\text { (\%) }\end{array}$ & $\stackrel{\mathrm{pH}}{(\mathrm{H} 2 \mathrm{O})}$ & $\stackrel{\mathrm{pH}}{(\mathrm{KCl})}$ & $\begin{array}{l}\text { Coarse } \\
\text { sand } \\
2.0-0.2 \\
\mathrm{~mm}\end{array}$ & $\begin{array}{l}\text { Fine } \\
\text { sand } \\
\\
0.2- \\
0.063 \\
\mathrm{~mm}\end{array}$ & $\begin{array}{l}\begin{array}{l}\text { Coarse } \\
\text { silt }\end{array} \\
0.063- \\
0.02 \mathrm{~mm}\end{array}$ & $\begin{array}{l}\text { Fine silt } \\
0.02- \\
0.002 \\
\mathrm{~mm}\end{array}$ & $\begin{array}{l}\text { Clay } \\
<0.002 \\
\mathrm{~mm}\end{array}$ & $\begin{array}{l}\text { Texture } \\
\text { class }\end{array}$ \\
\hline 39 & Vrapče & 6.77 & 3.95 & 5.3 & 7.8 & 7.2 & 25.4 & 14.2 & 22.4 & 30.4 & 7.6 & $\mathrm{Prl}$ \\
\hline 40 & Podsused & 34.1 & 25.5 & 14.0 & 7.7 & 7.0 & 49.7 & 15.7 & 19.3 & 11.8 & 3.5 & $\mathrm{PI}$ \\
\hline 41 & Podsused & 3.94 & 2.34 & 5.5 & 7.7 & 7.4 & 41.9 & 15.6 & 16.3 & 21.5 & 4.7 & $\mathrm{Pl}$ \\
\hline 42 & Zaprešić & 28.4 & 16.7 & 15.7 & 7.8 & 7.0 & 53.3 & 11.8 & 11.3 & 16.4 & 7.2 & $\mathrm{Pl}$ \\
\hline 43 & Zaprešić & 12.4 & 5.92 & 9.2 & 7.7 & 7.1 & 34.5 & 16.3 & 16.4 & 25.3 & 7.5 & $\mathrm{PI}$ \\
\hline 44 & Zaprešić & 97.6 & 13.3 & 15.0 & 7.7 & 7.1 & 52.4 & 15.0 & 12.9 & 13.9 & 5.8 & $\mathrm{Pl}$ \\
\hline 45 & Novi Dvori & 4.31 & 1.95 & 8.7 & 7.6 & 7.1 & 28.1 & 16.8 & 18.1 & 28.8 & 8.2 & I \\
\hline 46 & Novi Dvori - Zaprešić & 6.80 & 4.45 & 9.5 & 7.7 & 6.8 & 19.8 & 6.0 & 14.3 & 34.8 & 25.1 & 1 \\
\hline 47 & Pojatno & 5.38 & 2.80 & 7.4 & 7.6 & 6.9 & 18.8 & 18.1 & 17.0 & 32.0 & 14.1 & I \\
\hline 48 & Kupljenovo & 3.04 & 2.49 & 4.6 & 7.9 & 7.2 & 29.6 & 10.0 & 15.3 & 33.0 & 12.1 & 1 \\
\hline 49 & Luka & 9.62 & 7.41 & 10.9 & 7.8 & 7.2 & 69.4 & 8.7 & 9.1 & 11.0 & 1.8 & IP \\
\hline 50 & Žeinci & 61.4 & 43.2 & 11.5 & 7.6 & 7.0 & 29.1 & 11.5 & 15.7 & 34.2 & 9.5 & I \\
\hline 51 & Vekiko Trgovišće & 20.7 & 25.3 & 13.1 & 7.7 & 7.0 & 34.2 & 8.9 & 15.4 & 31.7 & 9.8 & I \\
\hline 52 & Vekiko Trgovišće & 4.55 & 1.54 & 4.3 & 7.8 & 7.1 & 15.2 & 16.7 & 16.8 & 38.6 & 12.7 & $\mathrm{Prl}$ \\
\hline 53 & Zabok & 6.22 & 2.17 & 7.8 & 7.8 & 7.0 & 18.8 & 10.3 & 22.5 & 38.0 & 10.4 & Prl \\
\hline 54 & Zabok & 3.83 & 2.89 & 9.3 & 7.8 & 7.0 & 46.4 & 18.9 & 15.2 & 13.7 & 5.8 & $\mathrm{PI}$ \\
\hline 55 & Hum Lug & 4.88 & 3.40 & 6.2 & 7.7 & 7.1 & 39.4 & 20.6 & 20.2 & 16.3 & 3.5 & $\mathrm{PI}$ \\
\hline 56 & Dubrava Zabočka & 6.50 & 2.79 & 7.0 & 7.4 & 6.9 & 17.6 & 23.8 & 24.3 & 26.0 & 8.3 & $\mathrm{Prl}$ \\
\hline 57 & Špičkovina & 6.12 & 4.53 & 3.2 & 7.8 & 7.5 & 71.3 & 10.0 & 8.6 & 8.7 & 1.4 & IP \\
\hline 58 & $\begin{array}{l}\text { Poznanovec - } \\
\text { Bedekovčina }\end{array}$ & 6.23 & 2.97 & 6.9 & 7.6 & 7.1 & 16.2 & 26.8 & 27.7 & 22.6 & 6.7 & $\mathrm{Prl}$ \\
\hline 59 & Bedekovčina & 6.52 & 2.89 & 8.3 & 7.8 & 7.1 & 24.1 & 16.0 & 21.1 & 26.6 & 12.2 & 1 \\
\hline \multirow[t]{6}{*}{60} & Bedekovčina & 13.3 & 2.85 & 4.4 & 7.9 & 7.1 & 24.9 & 23.2 & 20.7 & 22.1 & 9.1 & 1 \\
\hline & Average & 13.21 & 7.13 & 7.3 & & & 33.4 & 14.7 & 20.7 & 23.9 & 7.27 & \\
\hline & Median & 7.89 & 3.04 & 7.0 & & & 29.9 & 15.0 & 19.2 & 24.2 & 6.75 & \\
\hline & Maximum & 97.6 & 52.0 & 17.7 & 8.05 & 7.90 & 81.0 & 26.8 & 55.3 & 49.0 & 28.5 & \\
\hline & Minimum & 3.04 & 0.98 & 1.00 & 6.70 & 5.84 & 0.70 & 2.20 & 3.70 & 3.90 & 0.50 & \\
\hline & Background sample & 4.13 & 1.67 & & & & & & & & & \\
\hline
\end{tabular}

\section{Discussion}

\section{Distribution of $\mathrm{Sb}$ and $\mathrm{Sn}$ in soil near railway tracks}

Tin and antimony are naturally present in the soil in certain amounts. According to Geochemical Atlas of Europe (Salminen et al. 2005), the median for Sb and $\mathrm{Sn}$ in European topsoil is $0.6 \mathrm{mg} / \mathrm{kg}$ and $3 \mathrm{mg} / \mathrm{kg}$, respectively. In the north-eastern part of Croatia, soils contain from 0.83 to $1.46 \mathrm{mg} / \mathrm{kg}$ of Sb and from 4.00 to $7.00 \mathrm{mg} / \mathrm{kg}$ of Sn (Salminen et al. 2005). The obtained data indicate not only a great variability of Sb and Sn contents, but also an exceptional enrichment of the soil with $\mathrm{Sb}$ and $\mathrm{Sn}$ at certain sites. Indeed, the $\mathrm{Sb}$ and $\mathrm{Sn}$ contents in the studied soils range from the minimum values close to the medians reported for European soils to the maximum values of $52.0 \mathrm{mg} / \mathrm{kg}$ for Sb and $97.6 \mathrm{mg} / \mathrm{kg}$ for Sn, with RSDs of $139 \%$ and $117 \%$, respectively. At the sites where the highest values were recorded, the mass fractions of Sb and Sn in the soil are 87 and 33 times higher, respectively, then the median for European soils; 36 and 14 times higher, respectively, then the highest value reported for north-eastern part of Croatia; and 31 and 24 times higher, respectively, then the background value for the studied area; clearly indicating the extreme contamination of the studied soils with these elements.

The literature clearly confirms rail transport as a source of soil pollution with numerous contaminants (Barcan et al. 1998; Brooks 2004; Bukowiecki et al. 2007; Burkhardt et al. 2008; Gehrig et al. 2007; Ikarashi et al. 2005; Jarvis et al. 2006; Kohler et al. 2000; Liu et al. 2009; Lorenzo et al. 2006; Malawska and Wiłkomirski 1999; Schweinsberg et al. 1999; Wierzbicka et al. 2015; Wiłkomirski et al. 2012; Zhang et al. 2012). However, data for Sb and Sn in soils near railways are extremely sparse and, to our knowledge, include only three studies conducted in Poland (Table 2). Dzierżanowski and Gawroński (2012) 
investigated $\mathrm{Sn}$ and $\mathrm{Sb}$ concentrations between railway stations in the suburbs of Warsaw, in the vicinity of two parallel railway tracks near stony railway embankments. Measurements were performed in situ with XRF instruments, and due to the high detection limits (less than $18 \mathrm{mg} / \mathrm{kg}$ and $218 \mathrm{mg} / \mathrm{kg}$ for Sn and Sb, respectively), Sn and Sb were not detected. Wiłkomirski et al. (2013) carried out investigations in the area of four railway stations in north-eastern Poland (Białystok, Sokółka, Hajnówka and Kuźnica) in different functional parts of the stations (the siding, the cleaning bay for rolling stock, the classification yard, the receiving yard and the hold yard). Sb was not determined and the maximum value of Sn was $23 \mathrm{mg} / \mathrm{kg}$ and was measured in the platform area.

Staszewski et al. (2015) conducted a study in northern Poland, at the lława Główna railway junction. Soil samples were collected between the rails and outside the rails to the end of the railway sleepers. For $\mathrm{Sn}$, concentrations were $2-5$ times higher compared to control samples, with the highest value of $33 \mathrm{mg} / \mathrm{kg}$ in the railway platform area, while $\mathrm{Sb}$ was not considered in the investigation.

A comparison of data from this study and the cited literature shows the highest recorded levels of Sn in soils near railways in Croatia, while for Sb the lack of data precludes further comparison.

Table 2

Published research on $\mathrm{Sn}$ and $\mathrm{Sb}$ along the railway

\begin{tabular}{|c|c|c|c|c|c|c|c|}
\hline $\begin{array}{l}\text { Literature } \\
\text { source }\end{array}$ & Country & Locality & $\begin{array}{l}\text { Functional part } \\
\text { of railway }\end{array}$ & $\begin{array}{l}\text { Distance from } \\
\text { the tracks }\end{array}$ & $\begin{array}{l}\text { Year of soil } \\
\text { samples } \\
\text { collection }\end{array}$ & $\begin{array}{l}\mathrm{Sn} \\
\mathrm{mg} / \mathrm{kg}\end{array}$ & $\begin{array}{l}\mathrm{Sb} \\
\mathrm{mg} / \mathrm{kg}\end{array}$ \\
\hline $\begin{array}{l}\text { Dzierżanowski } \\
\text { and Gawroński (2012) }\end{array}$ & Poland & $\begin{array}{l}\text { suburbs } \\
\text { of Warsaw }\end{array}$ & between stations & $\begin{array}{l}0-1 \mathrm{~m} \text { from the } \\
\text { track embankments }\end{array}$ & 2011 & $\begin{array}{l}\text { below } \\
\text { detection } \\
\text { limit }\end{array}$ & $\begin{array}{l}\text { below } \\
\text { detection } \\
\text { limit }\end{array}$ \\
\hline $\begin{array}{l}\text { Wiłkomirski } \\
\text { et al. (2013) }\end{array}$ & Poland & $\begin{array}{l}\text { Białystok, Sokółka, } \\
\text { Hajnówka and Kuźnica }\end{array}$ & $\begin{array}{l}\text { railway stations: } \\
\text { in different } \\
\text { functional parts }\end{array}$ & not specified & 2012 & $3-23$ & $\begin{array}{l}\text { not } \\
\text { investigated }\end{array}$ \\
\hline $\begin{array}{l}\text { Staszewski } \\
\text { et al. (2015) }\end{array}$ & Poland & Iława Główna & $\begin{array}{l}\text { railway } \\
\text { junction }\end{array}$ & $<2 \mathrm{~m}$ & 2008 & $4-33$ & $\begin{array}{l}\text { not } \\
\text { investigated }\end{array}$ \\
\hline
\end{tabular}

\section{Properties that affect the content of $\mathrm{Sn}$ and $\mathrm{Sb}$ in the soil}

The levels of HMs, including Sb and Sn, in soil are influenced by both natural and anthropogenic factors; whereby natural ones include physical, chemical, biological, and climatological factors; while anthropogenic refer to various types of pollution and degradation.

\section{Influence of soil properties}

In order to identify the role of different natural factors (grain size distribution, texture, humus content, $\mathrm{pH}$ ) affecting the content of $\mathrm{Sb}$ and $\mathrm{Sn}$ in studied soils, their relationship was examined by the principal component analysis (PCA). The eingenvalues of the first four principal components (PCs) were larger than 1 , indicating their significance and explaining $75.4 \%$ of the total variability among 11 variables. Thereby, the first component (PC1) contributed $34.5 \%$, while the second, the third and the fourth corresponded to $17.6 \%, 13.2 \%$ and $10.3 \%$, respectively, of the total variance of the data set. Results of PCA are presented on the PCA loading plots (Fig. 2a and b), illustrating the orientation of the variables with respect to principal components. On PC1 vs PC2 plot (Fig. 2a), the highest negative PC1 loadings exhibited fine and coarse silt (-0.84 and 0.80, respectively), while coarse sand content and $\mathrm{pH}_{\mathrm{KCl}}$ displayed positive PC1 loadings (0.93 and 0.81, respectively). The humus, Sb and Sn content exhibited the greatest negative effect on PC2 (from - 0.82 to -0.71 ), whereas none of the studied parameters showed positive values (>0.5) with respect to this component. On PC3 vs PC4 plot (Fig. 2b), the highest negative PC3 loadings exhibited texture (-0.66), whereas fine sand displayed positive PC3 loading (0.51). The pH and $\triangle \mathrm{pH}$, exhibited the greatest positive effect on PC4 (0.70 and 0.71 , respectively), whereas none of the studied parameters showed negative $(<-0.5)$ values with respect to this component.

According to Fig. 2a, the variation of the data is mainly influenced by the soil texture, especially by the ratio of finer (coarse silt, fine silt and clay) and larger fractions (coarse sand) in the soil itself. While the influence of the finest fraction of the soil as a metal carrier is well known (Rieuwerts et al. 1998), the results show the significant influence of the largest fraction on the distribution of $\mathrm{Sb}$ and $\mathrm{Sn}$. To some extent, this is to be expected, as the soil texture near railway embankments is not entirely of natural origin, i.e. formed by decomposition of the parent substrate. Indeed, on railway embankments there are gravel stones and with increasing distance from the tracks such material is replaced by natural soil. The next factor affecting the content of Sb and $\mathrm{Sn}$ in the studied soils is the humus content (Fig. 2a). This is consistent with previous findings suggesting higher adsorption of metals in soils with higher organic matter content and cation exchange capacity (Rieuwerts et al. 1998; Young 2013). As can be seen in Fig. 2b, the following factors influencing the variance of the data are the texture (class) of the soil and the soil pH.

\section{Influence of distance from railway}

One of the factors affecting the mass fractions of $\mathrm{Sn}$ and $\mathrm{Sb}$ in the topsoil is the distance of sampling sites from the railway as a linear source of pollution. Different authors have studied gradients at different distances from the tracks, e.g. Baltrenas et al. (2009) at 1, 2, 3, 5, 10, 15, 25, 50 and 75 m; Bobryk (2015) 
and Bobryk et al. (2016) at 0, 25, 50, 100 and $250 \mathrm{~m}$; Chen et al. (2014a, b) at 1, 5, 15, 20 and $50 \mathrm{~m}$; Liu et al. (2009) at 2, 10, 25, 50, 100 and 150 m; Ma et al. (2009) at 0, 10, 20, 30, 50, 100, 200, 300, $500 \mathrm{~m}$ from the track edge; Malawska and Wiłkomirski (2000) at 0, 15, 30, 50 and 100 m; Mazur et al. (2013) at 2, 10, 20 and $30 \mathrm{~m}$ from the railway line; Meng et al. (2018) at 5, 10, 25, 50, 100 and $150 \mathrm{~m}$; Radziemska et al. (2016) at 1, 10, 20 and $30 \mathrm{~m}$ from the railway line; Samarska and Zelenko (2018b) at 5, 10, 15, 20, 30, 50, 100 m; Šeda et al. (2017) at 1.5, 3, 10 and 25 m; Stojic et al. (2017) at 0.03-4.19 km from the railway; Vaiškūnaitè and Jasiūnienè (2020) at 1, 5, 10, 15 and $25 \mathrm{~m}$ from the sleepers; Zhang et al. (2012) at 2, 5, 10, 20, 30, 50, 60, 70, 80, 100, 150 and 200 m from the railway; Zhang et al. (2013) at 2, 5, 10, 20, 30, 50, 60, 70, 80, 100, and $150 \mathrm{~m}$ from the embankment bottom. In the majority of the reported studies and for most of the investigated chemical elements, the general conclusion is that their mass fractions decrease with increasing distance from the railway tracks. The results of this study are consistent with such observations. Indeed, the measured Sb and Sn soil contents showed a decrease with increasing distance from the rails, although this decrease was not linear (Fig. 3a and b). By dividing the samples by distance into the following categories, $1 \mathrm{~m}, 1-2 \mathrm{~m}, 2-3 \mathrm{~m}, 3-5 \mathrm{~m}$ and 5-10 m (Fig. 4a and b), a statistically significant difference $(p<0.05)$ between the above groups was found only for Sb. Moreover, for both elements, an initial decrease in content was followed by an increase (at a distance of 2 to $3 \mathrm{~m}$ ) and a further decrease.

A similar observation was made by other authors as well. According to Ma et al. (2009), the highest contents for Ni, Cr and Cu were measured at about 10-30 $\mathrm{m}$ distance. Mazur et al. (2013) recorded the highest Ni contents at a distance of $20 \mathrm{~m}$, and for Cr and Co at a distance of 10 or $20 \mathrm{~m}$, depending on the study site. Meng et al. (2018) found that Cd showed an increasing trend from 5 to $50 \mathrm{~m}$. A possible explanation for this distribution pattern is related to the exhaust gasses, which can migrate with the airflow and deposit off-track (Ma et al. 2009). Based on the obtained results, different authors define safety distances for agricultural production. Šeda et al. (2017) stated that the safety distance is about $10 \mathrm{~m}$, Vaiškūnaite and Jasiūnienè (2020) defined the safety distance to the railway stations as $15 \mathrm{~m}$, while Baltrenas et al. (2009) stated that it should be $15 \mathrm{~m}$ or more. In agreement with the study by Liu et al. (2009), in China, areas within a $15 \mathrm{~m}$ distance along railways are regulated as safety zones and the cultivation of crops is prohibited in this area. However, the authors emphasize that the influence of $\mathrm{Mn}, \mathrm{Zn}$, and Cd can extend beyond 15 meters, so crops at these distances can still carry a potential risk of pollution from these HMs. Meng et al. (2018) stated that in China, crops and cropland should not be planted within $30 \mathrm{~m}$ of the railway line, and they suggested an even greater distance because the influence of HMs on soils can spread even further.

\section{Influence of site functionality}

Functional parts of railway infrastructure have a significant influence on soil Sn and Sb content according to the results of this study. As shown in Fig. 5, for both elements, the lowest mean mass fractions were measured along lines between stations, higher ones at stops, even higher ones at stations, and the highest ones at large junction stations. Indeed, the most contaminated sites are located near large junction stations such as Varaždin, Zagreb Main Station and Zaprešić.

However, unexpectedly high levels of $\mathrm{Sn}(61.4 \mathrm{mg} / \mathrm{kg})$ and $\mathrm{Sb}(43.2 \mathrm{mg} / \mathrm{kg})$ were found in the soil at Žeinci stop. A possible explanation is that a large amount of cargo or another substance (e.g. fuel) containing these two elements was spilled at this site in the past. It is also interesting to note that the maximum concentration of $\mathrm{Sb}(52.0 \mathrm{mg} / \mathrm{kg})$ was found at the Konjščina station, which could be the result of mining activities in the past, from 1885 to 1962 . Lignite (coal) was mined near Konjščina, which is known to contain antimony; and the coal was loaded and unloaded near the soil sampling point.

Statistically, a significant difference $(p<0.05)$ was found between the sites in terms of functionality for $\mathrm{Sb}$, while this was not the case for $\mathrm{Sn}$.

The dependence of $\mathrm{HM}$ concentrations and functional parts of railway infrastructure was systematically studied only by a group of researchers from Poland. Malawska and Wiłkomirski (2000) in their study distinguished the following functional parts of junctions: loading ramp, platform area, vehicle cleaning facility, the siding, and parts along the tracks outside the stations. They found the highest contamination with HMs at the loading ramp and the lowest along the tracks. The same authors, but in a different area, found the highest contamination at the cleaning bay and in the siding area (Malawska and Wiłkomirski, 2001). In the work of Wiłkomirski et al. (2011), the highest HM metal levels were found at the siding and in the platform area. Mętrak et al. (2015) found no typical pollution profiles for the differently used areas of railway, while Staszewski et al. (2015) established the highest soil contamination in the platform area.

\section{Influence of site topography}

Although scarcely studied, topography has a very important influence on the distribution of pollution in the environment. Liu et al. (2009) pointed out that the topography profile influences the metal level and distribution pattern along the railway. The elevated concentrations of HMs varied from $5 \mathrm{~m}$ to $100 \mathrm{~m}$ away from the tracks depending on the topography and elements.

In this study, the highest Sb and Sn soil contents were found in areas located at the same level as the railway line, while they were lower in locations either above or below the railway level (Fig. 6a and b), confirming the influence of topography on their spatial distribution. Moreover, a statistically significant difference $(p<0.05)$ between sites in terms of topography was again found only for Sb. Chen et al. (2018) made the same observations and attributed them to leaching and erosion. As one of the possible solutions to prevent the spreading of pollutants from railways Vo et al. (2015) suggest stormwater management.

\section{Influence of railway age}

Chen et al. (2014a) investigated the effect of railway operating time on contamination levels. Their results indicate an increase in contaminant levels (Cd and $\mathrm{Pb}$ ) with the duration of railway operating time. Wiłkomirski et al. (2011), in comparative studies at the same sites conducted in 1995-2008 (after 13 years), indicated a significant increase in PAH levels in the area of the railway junction during this period, although the same was not observed for HM concentrations. In fact, elevated HM concentrations were observed only in some studied locations. 
According to statistical analysis, the age of the track, i.e. the time of pollutant accumulation, has a statistically significant influence on Sb concentrations, although both $\mathrm{Sb}$ and $\mathrm{Sn}$ show slightly higher values in soils sampled near older railway tracks (Fig. 7a and b).

\section{Anthropogenic sources of soil pollution with $\mathrm{Sn}$ and Sb}

For pollutants such as Sn and Sb, very few studies were conducted along the tracks, although the rail network is quite extensive worldwide and is a well-known source of pollution. In general, studies of HMs along railways, compared to urban and industrial areas, are relatively rare as they are considered trivial (Chen et al. 2014a). Wiłkomirski et al. (2012) pointed out that there are surprisingly few reports in the scientific literature describing environmental problems caused by rail transport, while Popp and Boyle (2017) emphasized that there is a conspicuous lack of research related to railways and their impact on wildlife. This is especially true since the study of HMs in dust (which in dry and wet deposition ends up in the soil) in various urban functional areas in the city of Shijiazhuang (North China) revealed that the area around the North Railway Station is among the most polluted (Wan et al. 2016). Similarly, Chillrud et al. (2005) studied steel dust in the form of particulate matter (PM) in the New York City subway and found that the levels of Fe, Mn, and Cr were more than 100 times higher than outdoors. Other elements that were above the outdoor mean included $\mathrm{Ag}, \mathrm{Al}, \mathrm{As}, \mathrm{Cu}, \mathrm{Sn}$, and Sb. Possible sources of these elements were suggested to be contact points of electrical relays and switches, composite metal breaker pads, and trace impurities in some types of steel. A computational estimate of significant pollutant sources and levels from the Swiss Federal Railways (SBB) network in 2003 indicated that particulate matter was the dominant form of pollution (Burkhardt et al. 2008). The main substances introduced by regular railway operations include metals (about $2270 \mathrm{t} / \mathrm{year}$ ), hydrocarbons (1357 t/year) and herbicides (3.9 t/year). Among these, the main emission of PM is generated by abrasion of brakes (73\%), rails (21\%), wheels (5\%) and overhead lines (1\%). In this context, the abrasion of iron sintered brakes, which may contain $0.09 \% \mathrm{Sn}$ and $0.01 \% \mathrm{Sb}$ among other metals, is considered as a possible source of contamination of the surrounding soil with these two elements. In addition, Zn-Sn and Cd-Sn alloys have also been reported as commonly used coatings in hydraulic brakes (Adriano 2001). Furthermore, Clemente (2013) suggested that the use of Sb as a fire retardant in brake linings emits significant amounts from vehicles into the environment. Furthermore, Sn is released into the environment by burning of fossil fuels (coal and oil) and exists in the atmosphere as gases and fumes and attached to dust particles (Cima 2018).

All the above can be considered as additional sources of $\mathrm{Sb}$ and $\mathrm{Sn}$ in soils along railway lines, which in the present study conditioned the mass fractions of $\mathrm{Sb}$ higher than the upper limit for regional soils (Salminen et al. 2005) for a total of 51 samples and in 16 sites by a factor of 5 and higher. A similar situation was observed for $\mathrm{Sn}$, where the content above the upper limit for regional soils (Salminen et al. 2005) was measured at 39 sites, while this factor was higher than 5 at only three sites.

In general, rail transport is considered a diverse source of HMs introduced by various activities, including freight transport, friction in systems; wheel-brake blocks, wheel-rail, pantograph contact wire, bearings; use of herbicides; coal heating of cars; exhaust fumes from locomotive engines; migration from wooden and reinforced concrete sleepers, from rubble and ballast cut-off materials; garbage discarded from trains and on platforms, etc. (Samarska and Zelenko 2018a). In line with that, Staszewski et al. (2015) pointed out that the levels of metals in soil near railways are higher than the corresponding values found along traffic roads and in city centres. Similar results were obtained by research in the city of Varaždin in northwestern Croatia (unpublished data), where the highest concentrations of HMs in topsoils were found in the area of the railway station. According to the above, railway stations in the urban areas, and very often located in the centres of cities, are points of very high emissions of pollutants, which should not be neglected.

\section{Future perspectives}

Currently, neither $\mathrm{Sn}$ nor Sb are usually included in the existing regulations, including the existing Croatian maximum permissible metal levels in soil (OG 09/14). According to the Croatian Agricultural Soil Protection Policy (OG 20/18, 115/18), the maximum permissible concentrations of HMs are defined, but tin and antimony are not included on this list. According to the European Chemicals Agency (ECHA 2020a, b), antimony is recognized as a toxic element, while tin is not considered harmful to humans and the environment.

However, both elements are in certain chemical forms toxic to humans and living organisms (Cima 2018; Cooper and Harrison 2009). Recent extensive research in Europe conducted by Eze et al. (2020) has shown that railway transport, particularly long-term exposure to noise and air pollution, affects human health and causes DNA methylation associated with inflammation and immune responses, and thus accelerates biological aging and causes various diseases (respiratory, cardiovascular, and others). In addition to the negative impacts of rail traffic on human health, negative impacts on ecosystems and wildlife have also been confirmed (Barrientos et al. 2019). The fact that synergistic effect of even low concentrations, below permissible values, of several pollutants together can have a toxic effect on organisms of different trophic levels (Wierzbicka et al. 2015), should also be considered.

It is, thus, crucially important to determine the presence of tin and antimony in soil along roads and railways, as well as chemical forms of $\mathrm{Sn}$ and $\mathrm{Sb}$ in order to properly assess their potential toxicity.

\section{Conclusions}

In the study area, the railway has been in operation for more than 150 years, connecting the capital of Croatia, with a population of over one million, with the surrounding smaller settlements and towns. Soil collected at 60 sites along the $160 \mathrm{~km}$ railway line showed significant enrichment of antimony and tin, up to 31 and 24 times higher, respectively, then background levels at some sites.

The elevated Sb and Sn levels in the studied soils are believed to be determined by a number of natural and anthropogenic factors. Among the natural factors, the distribution of $\mathrm{Sb}$ and $\mathrm{Sn}$ in the soil was found to be primarily determined by gravel content (track ballast), which is an indirect indicator of distance from the railway, followed by humus content, soil texture and $\mathrm{pH}$. Extensive data analysis showed that this influence depends on the distance from the tracks, the functional part of the railway, the topography of the site, and generally increases with railway operation time. In terms of possible anthropogenic factors, the

Page 9/16 
literature points to numerous sources of $\mathrm{Sb}$ and $\mathrm{Sn}$ in rail transport that could consequently influence soil content, including friction in equipment, composition of alloys, wires and bearings, use of herbicides, exhaust fumes, spillage of freight, etc.

The observed extreme soil contamination with antimony and tin, for which numerous studies indicate a possible toxic effect, certainly calls for more detailed studies and the establishment of safety distances that will ensure the least possible impact of rail transport on nearby crops and prevent the entry of these elements into the food chain. In establishing such safety distances, one should certainly take into account not only the distance from the rails, but also the functional parts of the line, the topography of the terrain, the frequency of traffic, the type of fuel used, the type of cargo, etc.

\section{Declarations}

Acknowledgements The authors gratefully acknowledge the University of Zagreb, the Varaždin County and the Faculty of Geotechnical Engineering for funding the research.

Author contribution ZS conducted field research and was a major contributor in writing the manuscript. ŽF made statistical analyses. ŽF and AV participated in writing the paper. All authors read and approved the final version of the manuscript (paper).

Funding This study was funded by the University of Zagreb in 2014, project title: Potential for removal of heavy metals by phytoremediation along railways in northwestern Croatia; by the Varaždin County in 2014 and 2015, project title: Determination of heavy metals in soil and plant samples along the railway lines in the area of Varaždin County; and by the Faculty of Geotechnical Engineering in 2014, project title: Determination of heavy metals in soil and plant samples along the Varaždin - Zagreb railway line.

Ethics approval Not applicable.

Consent to participate Not applicable.

Consent for publication Not applicable.

Availability of data and materials All data generated or analysed during this study are included in this manuscript (article).

Competing interests/ Compliance with Ethical Standards The authors have no conflicts of interest to declare that are relevant to the content of this article.

\section{References}

1. Adriano DC (2001) Other trace elements. In: Adriano DC (ed) Trace elements in terrestrial environments: biogeochemistry, bioavailability, and risk of metals, 2nd edn. Springer-Verlag, New York, pp 759-796

2. Akoto O, Ephraim JH, Darko G (2008) Heavy Metals Pollution in Surface Soils in the Vicinity of Abundant Railway Servicing Workshop in Kumasi, Ghana. Int J Environ Res 2:359-364. https://doi.org/10.22059/ijer.2010.215

3. Alloway BJ (2013) Chap. 24: Tin. In: Alloway BJ (ed) Heavy metals in soils - Trace metals and metalloids in soils and their bioavailability, 3rd edn. Springer Science + Business Media Dordrecht, London, pp 551-558

4. Alok Gude L (2017) Heavy metal detection from sewage irrigated soil beside railway tracks in Mumbai. Kong Res J 4:121-128. https://doi.org/10.26524/krj188

5. Baltrenas P, Vaitiekunas P, Baciulyte Z (2009) Investigation of soil's contamination with heavy metals by railway transport. J Environ Eng Landsc 17:244251. https://doi.org/10.3846/1648-6897.2009.17.244-251 (in Lithuanian)

6. Barcan VS, Kovnatsky EF, Smetannikova MS (1998) Absorption of heavy metals in wild berries and edible mushrooms in an area affected by smelter emissions. Water Air Soil Poll 103:173-195. https://doi.org/10.1023/A:1004972632578

7. Barrientos R, Ascensăo F, Beja P, Pereira HM, Borda-de-Agua L (2019) Railway ecology vs. road ecology: similarities and differences. Eur J Wildlife Res 65:12. https://doi.org/10.1007/s10344-018-1248-0

8. Bobryk N (2015) Spreading and accumulation of heavy metals in soils of railway-side areas. Vísn Dnípropetr Univ Ser Bíol Ekol 23:183-189. https://doi.org/10.15421/011526 (in Ukranian)

9. Bobryk N, Kryvtsova M, Nikolajchuk V, Voloshchuk I (2016) Response of soil microflora to impact of heavy metals in zones of influence of railway transport. Vísn Dnípropetr Univ Ser Bíol Ekol 24:151-156. https://doi.org/10.15421/011618 (in Ukrainian)

10. Brooks KM (2004) Polycyclic aromatic hydrocarbon migration from creosote-treated railway ties into ballast and adjacent wetlands. Research Paper FLPRP-617. Department of Agriculture, Forest Service, Forest Products Laboratory, Madison

11. Bukowiecki N, Gehrig R, Hill M, Lienemann P, Zwicky CN, Buchmann B, Weingartner E, Baltensperger U (2007) Iron, manganese and copper emitted by cargo and passenger trains in Zürich (Switzerland): Size-segregated mass concentrations in ambient air. Atmos Environ 41:878-889.

https://doi.org/10.1016/j.atmosenv.2006.07.045

12. Burkhardt M, Rossi L, Boller M (2008) Diffuse release of environmental hazards by railways. Desalination 226:106-113. https://doi.org/10.1016/j.desal.2007.02.102

13. Chen Z, Wang K, Ai Y, Li W, Gao H, Fang C (2014a) The effects of railway transportation on the enrichment of heavy metals in the artificial soil on railway cut slopes. Environ Monit Assess 186:1039-1049. https://doi.org/10.1007/s10661-013-3437-3 
14. Chen Z, Ai Y, Fang C, Wang K, Li W, Liu S, Li C, Xiao J, Huang Z (2014b) Distribution and phytoavailability of heavy metal chemical fractions in artificial soil on rock cut slopes alongside railways. J Hazard Mater 273:165-173. https://doi.org/10.1016/j.jhazmat.2014.03.042

15. Chen Z, Liu X, Ai Y, Chen J, Luo X, Chen J, Zhong S (2018) Effects and mechanisms of revegetation modes on cadmium and lead pollution in artificial soil on railway rock-cut slopes. Sci Total Environ 644:1602-1611. https://doi.org/10.1016/j.scitotenv.2018.06.380

16. Chillrud SN, Grass D, Ross JM, Coulibaly D, Slavkovich V, Epstein D, Sax SN, Pederson D, Johnson D, Spengler JD, Kinney PL, Simpson HJ, Brandt-Rauf P (2005) Steel dust in the New York City subway system as a source of manganese, chromium, and iron exposures for transit workers. $J$ Urban Health 82:33-42. https://doi.org/10.1093/jurban/jti006

17. Cima F (2018) Tin: Environmental Pollution and Health Effects. Reference Module in Earth Systems and Environmental Sciences. https://doi.org/10.1016/b978-0-12-409548-9.11198-4

18. Clemente R (2013) Chap. 18: Antimony. In: Alloway BJ (ed) Heavy metals in soils - Trace metals and metalloids in soils and their bioavailability, 3rd edn. Springer Science + Business Media Dordrecht, London, pp 497-506

19. Cooper RG, Harrison AP (2009) The exposure to and health effects of antimony. Indian J Occup Environ Med 13:3-10. https://doi.org/10.4103/00195278.50716

20. Dzierżanowski K, Gawroński SW (2012) Heavy metal concentration in plants growing on the vicinity of railroad tracks: a pilot study. Challenges of Modern Technology 3:42-45

21. ECHA (European Chemicals Agency) (2020a) Substance infocard: Antimony. https://echa.europa.eu/hechar/substanceinformation/-/substanceinfo/100.028.314. Accessed 29 July 2020

22. ECHA (European Chemicals Agency) (2020b) Substance infocard: Tin. https://echa.europa.eu/hr/substance-information/-/substanceinfo/100.028.310. Accessed 29 July 2020

23. Eze IC, Jeong A, Schaffner E, Rezwan FI, Ghantous A, Foraster M, Vienneau D, Kronenberg F, Herceg Z, Vineis P et al (2020) Genome-Wide DNA Methylation in Peripheral Blood and Long-Term Exposure to Source -Specific Transportation Noise and Air Pollution: The SAPALDIA Study. Environ Health Persp 128(6):067003. https://doi.org/10.1289/EHP6174

24. FAO (2006) Guidelines for soil description, 4th edn. FAO, UN, Rome

25. Fiket Ž, Mikac N, Kniewald G (2016) Mass Fractions of Forty-Six Major and Trace Elements, Including Rare Earth Elements, in Sediment and Soil Reference Materials Used in Environmental Studies. Geostand Geoanal Res 41:123-135. https://doi.org/10.1111/ggr.12129

26. Gehrig R, Hill M, Lienemann P, Zwicky CN, Bukowiecki N, Weingartner E (2007) Contribution of railway traffic to local PM10 concentration in Switzerland. Atmos Environ 41:923-933. https://doi.org/10.1016/j.atmosenv.2006.09.021

27. Gračanin M, Ilijanić L (1977) Introduction to plant ecology. Školska knjiga, Zagreb (in Croatian)

28. HRN ISO 10390:2005 Soil quality - Determination of pH (ISO 10390:2005). http://31.45.242.218/HZN/Todb.nsf/wFrameset2? OpenFrameSet\&Frame=Down\&Src=\%2FHZN\%2FTodb.nsf\%2F66011c0bda2bd4dfc1256cf300764c2d\%2F0e782f7e2e6cb750c1256fbd002d42ec\%3FOper Accessed 6 June 2020 (in Croatian)

29. HRN ISO 11464:2009 Soil quality - Pretreatment of samples for physico-chemical analysis (ISO 11464:2006). http://31.45.242.218/HZN/Todb.nsf/wFrameset2? OpenFrameSet\&Frame=Down\&Src=\%2FHZN\%2FTodb.nsf\%2Fcd07510acb630f47c1256d2c006ec863\%2F6a1dc151c271f96bc1257443002ee854\%3FOp $\epsilon$ Accessed 6 June 2020 (in Croatian)

30. HRN ISO 11277:2011 Soil quality - Determination of particle size distribution in mineral soil material - Method by sieving and sedimentation (ISO 11277:2009). http://31.45.242.218/HZN/Todb.nsf/wFrameset2?

OpenFrameSet\&Frame=Down\&Src=\%2FHZN\%2FTodb.nsf\%2Fcd07510acb630f47c1256d2c006ec863\%2Fb23c712f88d6b685c1257809005388c0\%3FOp Accessed 6 June 2020 (in Croatian)

31. Ikarashi Y, Kaniwa M, Tsuchiya T (2005) Monitoring of polycyclic aromatic hydrocarbons and water-extractable phenols in creosotes and creosote-treated woods made and procurable in Japan. Chemosphere 60:1279-1287. https://doi.org/10.1016/j.chemosphere.2005.01.054

32. Jarvis NJ, Almqvist S, Stenström J, Börjesson E, Jonsson E, Torstensson L (2006) Modelling the leaching of imazapyr in a railway embankment. Pest Manag Sci 62:940-946. https://doi.org/10.1002/ps.1261

33. JDPZ (1966) Tjurin method. Chemical methods of soil research. JDPZ, Beograd (in Serbian)

34. Kazantsev IV (2015) Rail transport is a source of soil contamination with heavy metals. Samara Journal of Science 2:94-96 (in Russian)

35. Kohler M, Künniger T, Schmid P, Gujer E, Crockett R, Wolfensberger M (2000) Inventory and emission factors of creosote, polycyclic aromatic hydrocarbons (PAH), and phenols from railroad ties treated with creosote. Environ Sci Technol 34:4766-4772. https://doi.org/10.1021/es000103h

36. Kowarik I (1986) Development of vegetation on urban land. Examples from Berlin (West) Tuexenia 6:75-98 (in German)

37. Liu H, Chen L-P, Ai Y-W, Yang X, Yu Y-H, Zuo Y-B, Fu G-Y (2009) Heavy metal contamination in soil alongside mountain railway in Sichuan, China. Environ Monit Assess 152:25-33. https://doi.org/10.1007/s10661-008-0293-7

38. Lorenzo R, Kaegi R, Gehrig R, Grobéty B (2006) Particle emissions of a railway line determined by detailed single particle analysis. Atmos Environ 40(40):7831-7841. https://doi.org/10.1016/j.atmosenv.2006.07.026

39. Ma J-H, Chu C-J, Li J, Song B (2009) Heavy Metal Pollution in Soils on Railroad Side of Zhengzhou- Putian Section of Longxi-Haizhou Railroad, China. Pedosphere 19:121-128. https://doi.org/10.1016/s1002-0160(08)60091-0

40. Malawska M, Wiłkomirski B (1997) Analysis of soil pollution by polichlorinated biphenyls (PCBs) and heavy metals (Cd, Pb) along railroads. Rocz Panstw Zakl Hig 48:343-349 (in Polish)

Page $11 / 16$ 
41. Malawska M, Wiłkomirski B (1999) An analysis of polychlorinated biphenyls (PCBs) content in soil and plant leaves (Taraxacum officinale) in the area of the railway junction Iława Główna. Toxicol Environ Chem 70:509-515. https://doi.org/10.1080/02772249909358773

42. Malawska M, Wiłkomirski B (2000) Soil and plant contamination with heavy metals in the area of the old railway junction Tarnowskie Góry and near two main railway routes. Rocz Panstw Zakl Hig 51:259-267

43. Malawska M, Wiłkomirski B (2001) An Analysis of Soil and Plant (Taraxacum officinale) Contamination with Heavy Metals and Polycyclic Aromatic Hydrocarbons (PAHs) in the Area of the Railway Junction Iława Główna, Poland. Water Air Soil Poll 127:339-349.

https://doi.org/10.1023/A:1005236016074

44. Mazur Z, Radziemska M, Maczuga O, Makuch A (2013) Heavy metal concentrations in soil and moss (Pleurozium schreberi) near railroad lines in Olsztyn (Poland). Fresen Environ Bull 22:955-961

45. Meng X, Ai Y, Li R, Zhang W (2018) Effect of heavy metal pollution on enzyme activities in railway cut slope soils. Environ Monit Assess $190: 197$. https://doi.org/10.1007/s10661-018-6567-9

46. Mętrak M, Chmielewska M, Sudnik-Wójcikowska B, Wiłkomirski B, Staszewski T, Suska-Malawska M (2015) Does the Function of Railway Infrastructure Determine Qualitative and Quantitative Composition of Contaminants (PAHs, Heavy Metals) in Soil and Plant Biomass? Water Air Soil Poll 226:253. https://doi.org/10.1007/s11270-015-2516-1

47. Murray P, Ge Y, Hendershot WH (2000) Evaluating three trace metal contaminated sites: a field and laboratory investigation. Environ Pollut 107:127-135. http://dx.doi.org/10.1016/S0269-7491(99)00120-7

48. OG (Official Gazette) 09/14: Ordinance on the protection of agricultural land against pollution. Narodne novine 09/2014 (in Croatian)

49. OG (Official Gazette) 20/18: Law on Agricultural Land. Narodne novine 20/2018 (in Croatian)

50. OG (Official Gazette) 115/18: Law on Amendments to the Law on Agricultural Land. Narodne novine 115/2018 (in Croatian)

51. Pollock SZ, St Clair CC (2020) Railway-Associated Attractants as Potential Contaminants for Wildlife. Environ Manage 66:16-29. https://doi.org/10.1007/s00267-020-01277-6

52. Popp JN, Boyle SP (2017) Railway ecology: Underrepresented in science? Basic App Ecol 19:84-93. https://doi.org/10.1016/j.baae.2016.11.006

53. Premec B (2020) Railway network map of Croatia. HŽ Infrastruktura d. o. o. https://www.hzinfra.hr/wp-content/uploads/2020/08/HZ_MREZA-PRUGA-278-2020.pdf. Accessed 5 February 2021

54. Radziemska M, Fronczyk J, Mazur Z, Vaverková M (2016) Impact of railway transport on soil and Pleurozium schreberi contamination with heavy metals. Infrastruct Ecol Rural Areas 1:45-57. http://dx.medra.org/10.14597/infraeco.2016.1.1.004 (in Polish)

55. Radziemska M, Gusiatin ZM, Kowal P, Bęś A, Majewski G, Jeznach-Steinhagen A, Mazur Z, Liniauskienė E, Brtnický M (2020) Environmental impact assessment of risk elements from railway transport with the use of pollution indices, a biotest and bioindicators. Hum Ecol Risk Assess. https://doi.org/10.1080/10807039.2020.1736984

56. Rieuwerts JS, Thornton I, Farago ME, Ashmore MR (1998) Factors influencing metal bioavailability in soils: preliminary investigations for the development of a critical loads approach for metals. Chem Spec Bioavailab 10:61-75. https://doi.org/10.3184/095422998782775835

57. Salminen R, Batista MJ, Bidovec M, Demetriades A, De Vivo B, De Vos W, Duris M, Gilucis A, Gregorauskiene V, Halamic J, Heitzmann P, Lima A, Jordan G, Klaver G, Klein P, Lis J, Locutura J, Marsina K, Mazreku A, O'Connor PJ, Olsson S, Ottesen R-T, Petersell V, Plant JA, Reeder S, Salpeteur I, Sandström H, Siewers U, Steenfelt A, Tarvainen T (2005) Geochemical Atlas of Europe. Part 1 - Background Information, Methodology and Maps. http://weppi.gtk.fi/publ/foregsatlas/maps_table.php. Accessed 17 June 2021

58. Samarska AV, Zelenko YV (2018a) Assessment of the railway influence on the heavy metal accumulation in soil. Science Transport Progress Bulletin of Dnipropetrovsk National University of Railway Transport 4(76):25-35. https://doi.org/10.15802/stp2018/140551

59. Samarska AV, Zelenko YV (2018b) The patterns of spreading and accumulating heavy metals in the railway infrastructure soils. Railway transport of Ukraine 3:13-21 (in Ukrainian)

60. Schweinsberg F, Abke W, Rieth K, Rohmann U, Zullei-Seibert N (1999) Herbicide use on railway tracks for safety reasons in Germany? Toxicol Lett 107:201-205. https://doi.org/10.1016/s0378-4274(99)00048-x

61. Šeda M, Šíma J, Volavka T, Vondruška J (2017) Contamination of soils with Cu, Na and Hg due to the highway and railway transport. Eurasian Journal of Soil Science 6:59-64. https://doi.org/10.18393/ejss.284266

62. Staszewski T, Malawska M, Studnik-Wójcikowska B, Galera H, Wiłkomirski B (2015) Soil and plants contamination with selected heavy metals in the area of a railway junction. Arch Environ Prot 41:35-42. https://doi.org/10.1515/aep-2015-0005

63. Stojic N, Pucarevic M, Stojic G (2017) Railway transportation as a source of soil pollution. Transport Res D-Tr E 57:124-129. https://doi.org/10.1016/j.trd.2017.09.024

64. Vaiškūnaitè R, Jasiūnienè V (2020) The analysis of heavy metal pollutants emitted by railway transport. Transport 35:213-223. https://doi.org/10.3846/transport.2020.12751

65. Vo PT, Ngo HH, Guo W, Zhou JL, Listowski A, Du B, Wei Q, Bui XT (2015) Stormwater quality management in rail transportation - Past, present and future. Sci Total Environ 512-513:353-363. https://doi.org/10.1016/j.scitotenv.2015.01.072

66. Wan D, Han Z, Yang J, Yang G, Liu X (2016) Heavy Metal Pollution in Settled Dust Associated with Different Urban Functional Areas in a Heavily AirPolluted City in North China. Int J Env Res Pub He 13:1119. https://doi.org/10.3390/ijerph13111119

67. Wierzbicka M, Bemowska-Kałabun O, Gworek B (2015) Multidimensional evaluation of soil pollution from railway tracks. Ecotoxicology $24: 805-822$. https://doi.org/10.1007/s10646-015-1426-8 
68. Wiłkomirski B, Sudnik-Wójcikowska B, Galera H, Wierzbicka M, Malawska M (2011) Railway transportation as a serious source of organic and inorganic pollution. Water Air Soil Poll 218:333-345. https://doi.org/10.1007/s11270-010-0645-0

69. Wiłkomirski B, Galera H, Sudnik-Wójcikowska B, Staszewski T, Malawska M (2012) Railway Tracks - Habitat Conditions, Contamination, Floristic Settlement - A Review. Environment Natural Resources Research 2:86-95. https://doi.org/10.5539/enrr.v2n1p86

70. Wiłkomirski B, Suska-Malawska M, Sudnik-Wójcikowska B, Staszewski T (2013) The selected trace elements in soil of railway stations in north-eastern Poland. Rocznik Świętokrzyski Ser B - Nauki Przyr 34:171-180

71. Young SD (2013) Chap. 3: Chemistry of heavy metals and metalloids in soils. In: Alloway BJ (ed) Heavy metals in soils - Trace metals and metalloids in soils and their bioavailability, 3rd edn. Springer Science + Business Media Dordrecht, London, pp 51-95

72. Zaninović K, Gajić-Čapka M, Perčec Tadić M, Vučetić M, Milković J, Bajić A, Cindrić K, Cvitan L, Katušin Z, Kaučić D, Likso T, Lončar E, Lončar Ž, Mihajlović D, Pandžić K, Patarčić M, Srnec L, Vučetić V (2008) Climate atlas of Croatia 1961-1990, 1971-2000. Državni hidrometeorološki zavod, Zagreb (in Croatian)

73. Zhang H, Wang Z, Zhang Y, Hu Z (2012) The effects of the Qinghai-Tibet railway on heavy metals enrichment in soils. Sci Total Environ $439: 240-248$. https://doi.org/10.1016/j.scitotenv.2012.09.027

74. Zhang H, Zhang Y, Wang Z, Ding M (2013) Heavy metal enrichment in the soil along the Delhi-Ulan section of the Qinghai-Tibet railway in China. Environ Monit Assess 185:5435-5447. https://doi.org/10.1007/s10661-012-2957-6

\section{Figures}

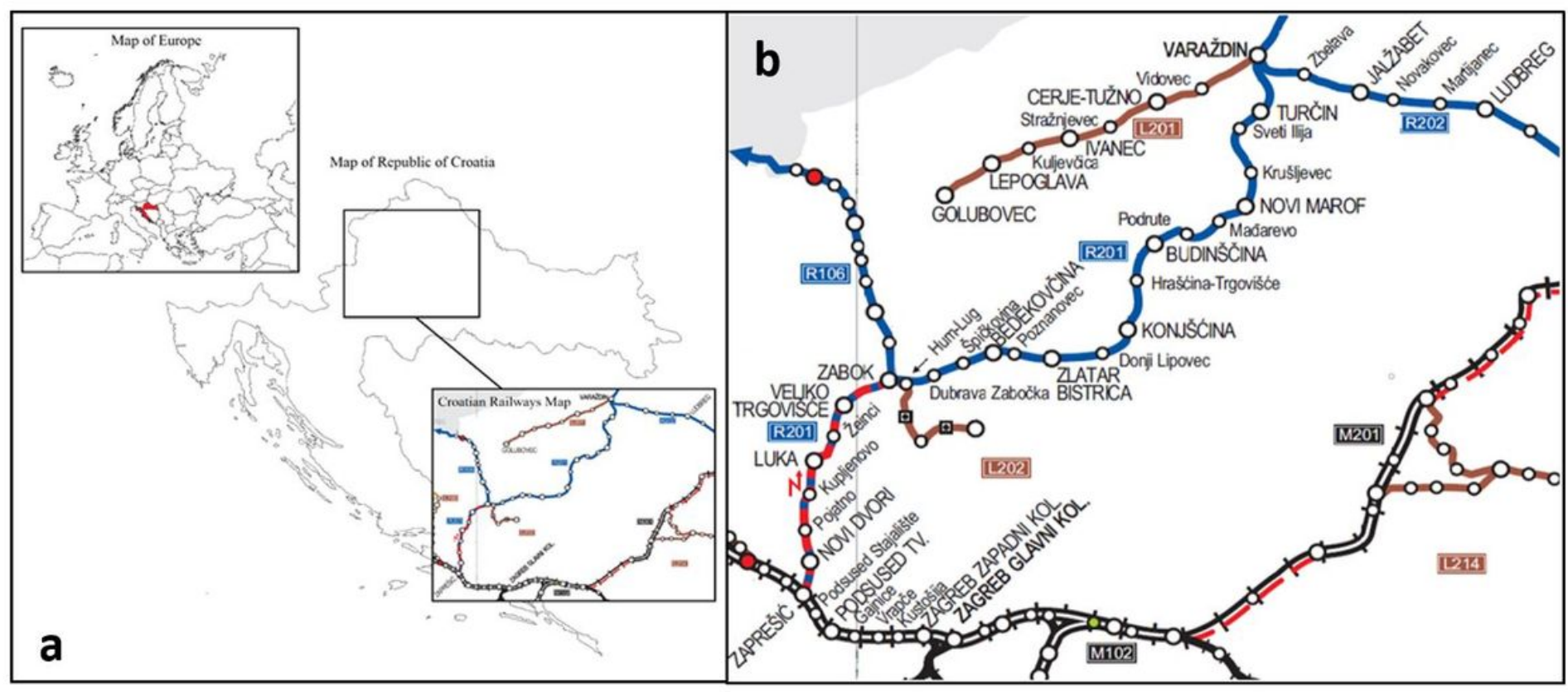

Figure 1

(a) The geographic location of the study area; (b) A more detailed view of studied railways (Croatian Railways Map: brown lines represent local railways, blue lines represent regional railway, bold black lines represent international railway (Premec 2020) 

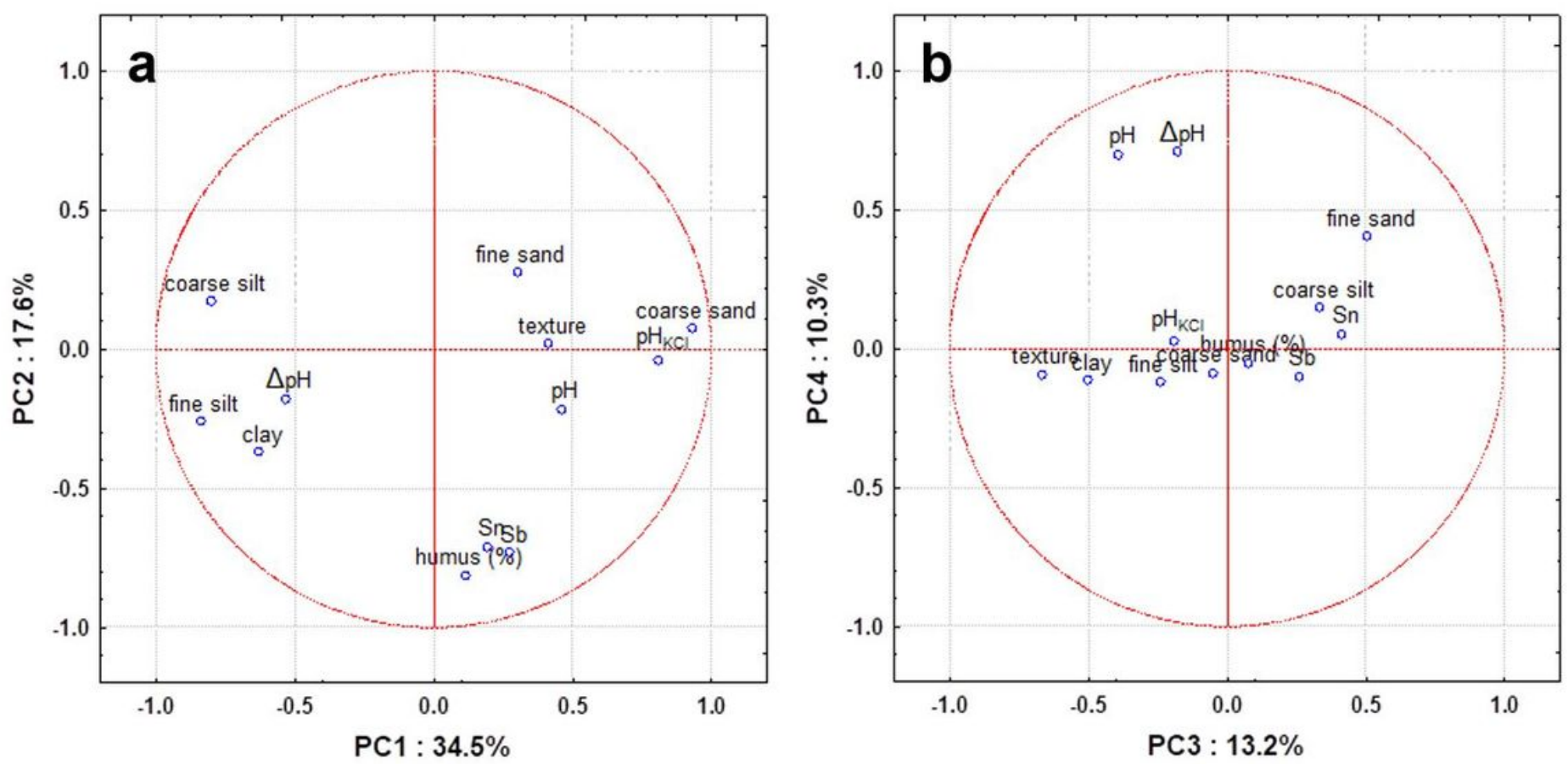

Figure 2

Principal component analysis: (a) PC1-PC2 and (b) PC3-PC4 loading plot
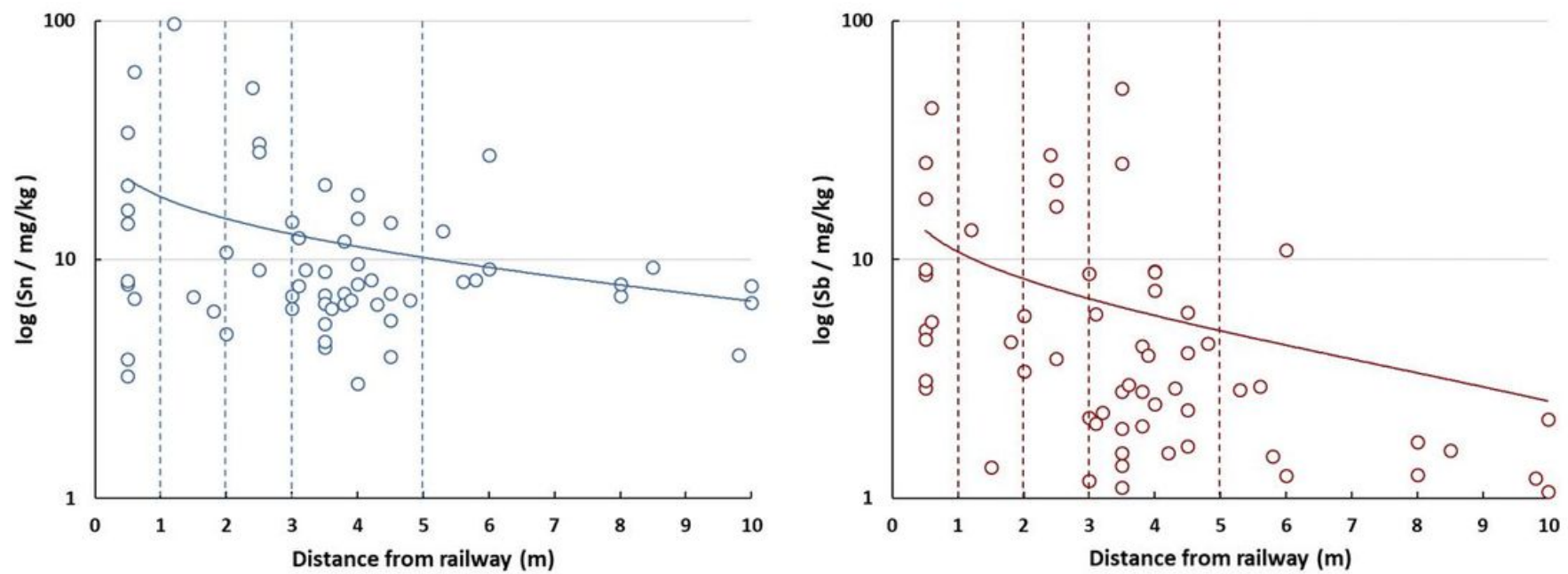

\section{Figure 3}

Dependence of the mass fraction of $\mathrm{Sn}(\mathrm{a})$ and $\mathrm{Sb}(\mathrm{b})$ in the soil, expressed in logarithmic form, and the distance of the sampling point from the railway tracks 

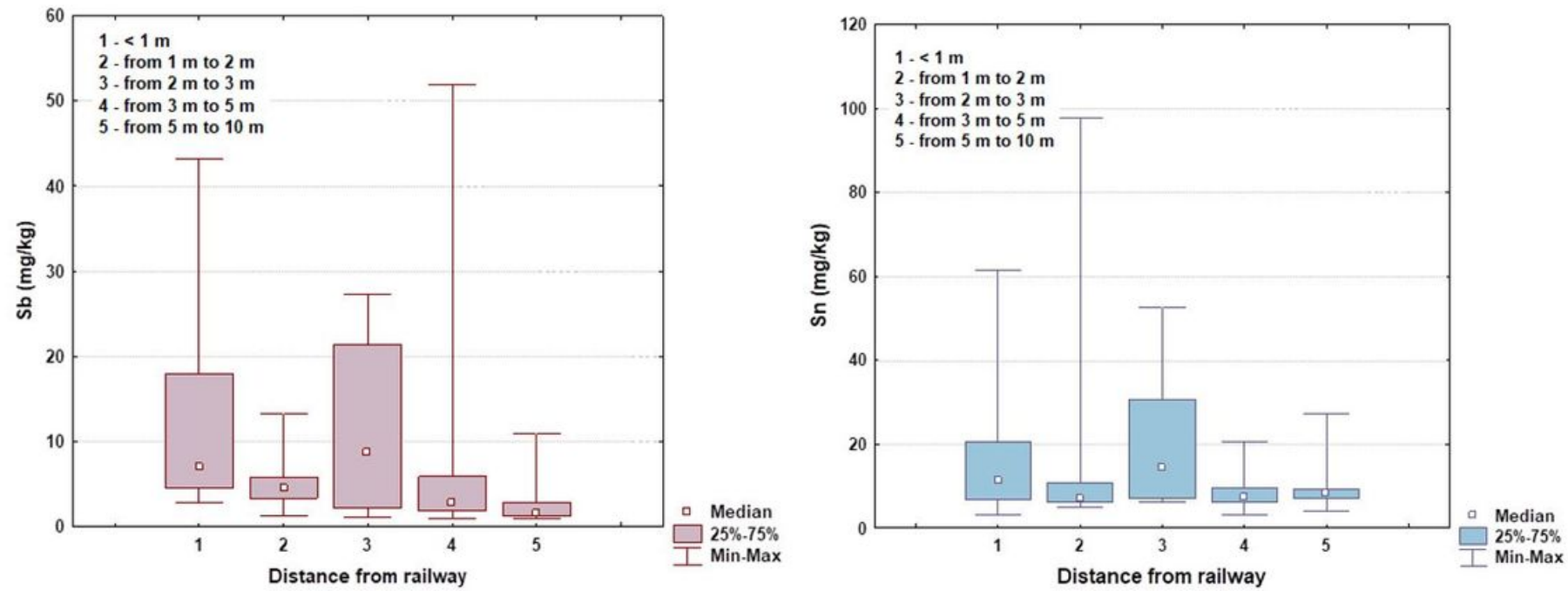

Figure 4

Dependence of mass fraction of $\mathrm{Sn}(\mathrm{a})$ and $\mathrm{Sb}(\mathrm{b})$ in soil and the distance categories of the sampling point from the railway tracks
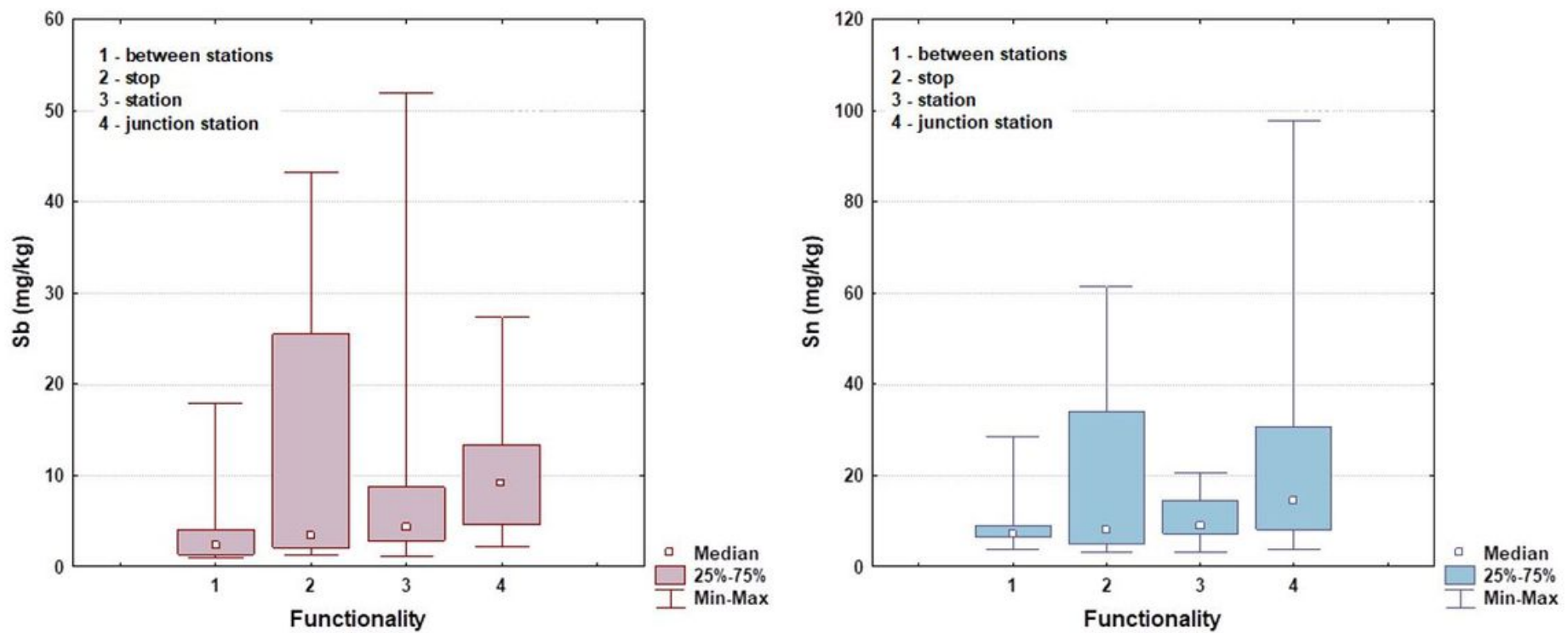

Figure 5

Dependence of mass fraction of Sn (a) and Sb (b) in soil and site functionality 

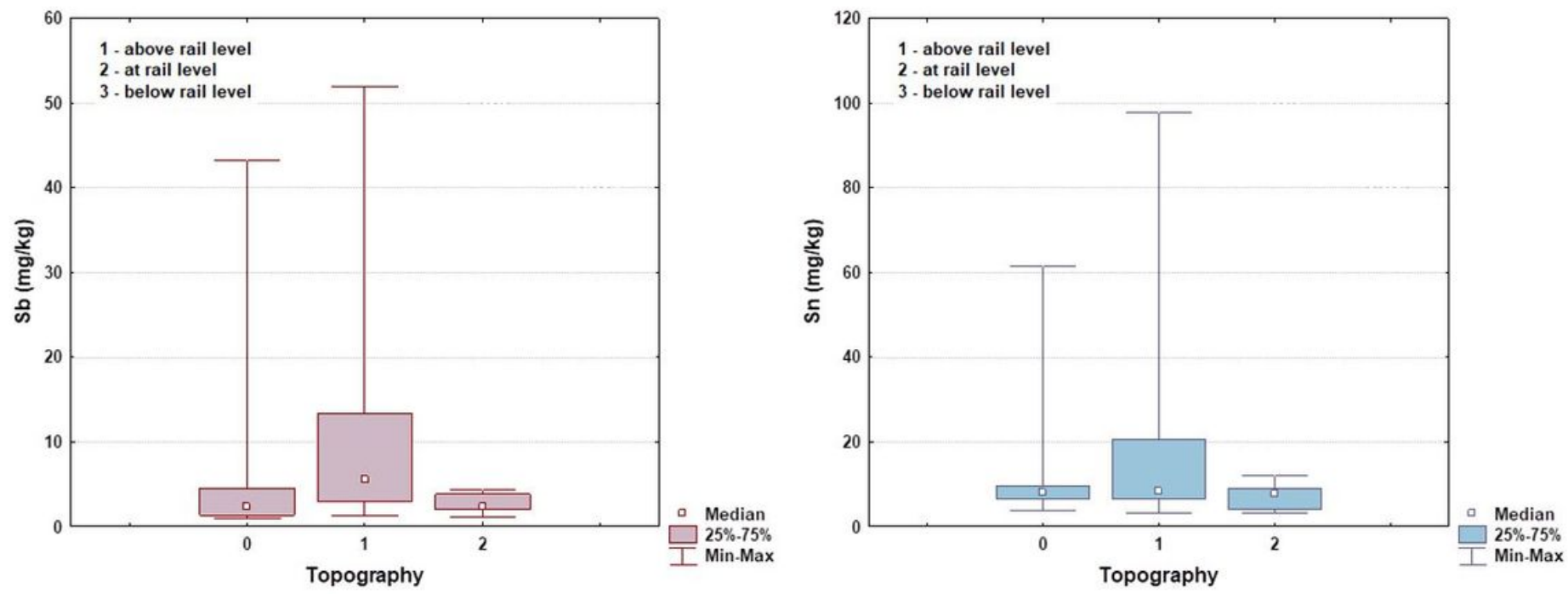

Figure 6

Dependence of mass fraction of Sn (a) and Sb (b) in soil and site topography
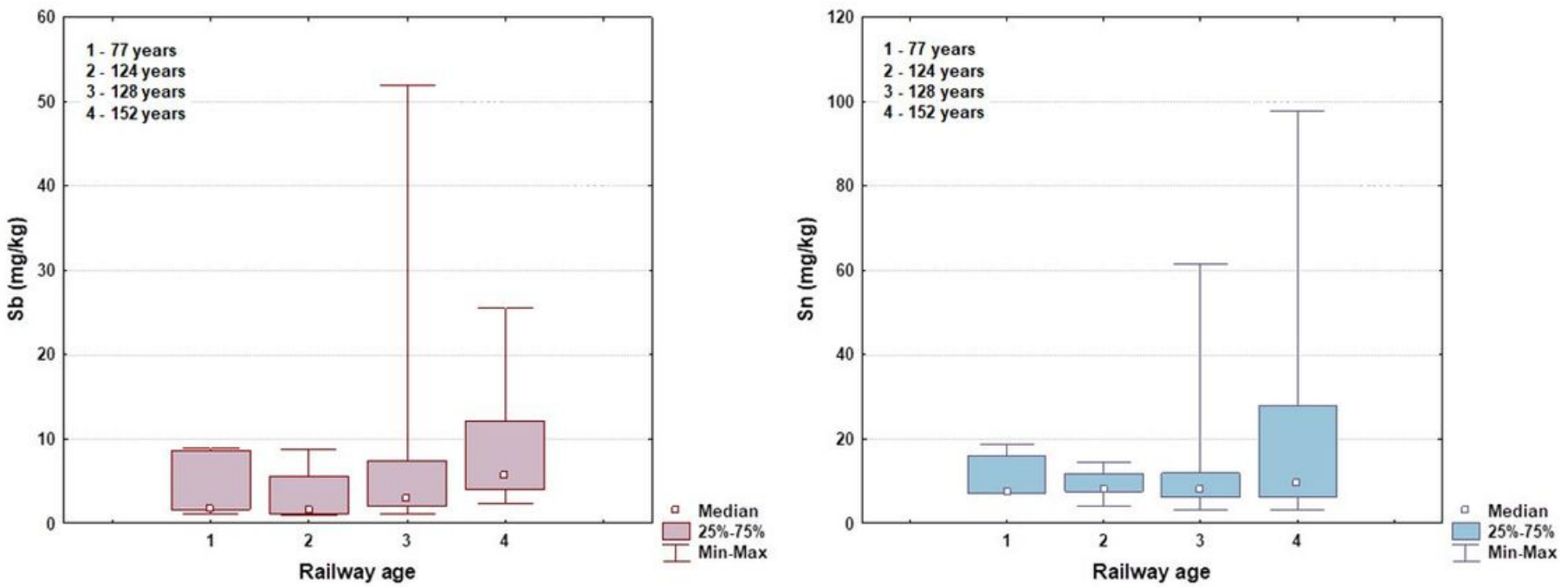

Figure 7

Dependence of mass fraction of $\mathrm{Sn}(\mathrm{a})$ and $\mathrm{Sb}(\mathrm{b})$ in soil and railway age 